\title{
THE IMPORTANCE PERFORMANCE ASSESSMENT AND ITS IMPACT ON IMPROVING PERFORMANCE OF PUBLIC SERVICE ORGANIZATIONS IN SOUTH TANGERANG CITY
}

\author{
Rahmat Salam \\ Muhamadiyah University Jakarta, Indonesia \\ E-mail: rahmat.salam@umj.ac.id
}

\begin{abstract}
So far, the performance appraisal of an organization is inaccurate because the assessment is only based on employee compliance with their superiors without providing an assessment based on the contribution made by the employee to the organization. This certainly impacts the employee's weak motivation, so that it can affect organizational performance, which affects the quality of public services. This research tries to present the analysis of employee performance appraisal by emphasizing the determined qualities (competencies) to improve the performance of public service organizations in Indonesia. It can be seen that performance measurement can be used as a reference as a measure of the performance of an organization. The research was conducted using a literature review study. And use a qualitative approach in analyzing the data presented in the study. The study found that their direct superiors generally evaluate employees. Concerning the frequency of promotion in o organization, each leader explains that the organization has a clear pattern in determining the promotion and position. This is the authority of management. However, sometimes organizational leaders allow biased factors such as gender issues, appearance problems, specific ethnicity or race or feelings of hatred towards someone. Affect their judgment. Unless appraisals are based on actual job performance, they will continue to be conducted without the goals often required in fair performance appraisal systems.
\end{abstract}

Keywords: Employee Performance; Performance Appraisal; Organization; Management; Public Service

\section{PENTINGNYA PENILAIAN KINERJA DAN DAMPAK TERHADAP PENINGKATAN KINERJA ORGANISASI PELAYANAN PUBLIK DI KOTA TANGERANG SELATAN}

\begin{abstract}
ABSTRAK. Selama ini penilaian kinerja sebuah organisasi kurang akurat karena penilaian hanya didasarkan kepatuhan pegawai kepada atasannya tanpa memberikan penilaian berdasarkan kontribusi yang dibuat pegawai tersebut kepada organisasi.Hal ini tentu sangat berdampak kepada lemahnya motivasi pegawai tersebut sehingga dapat berpengaruh kepada kinerja organisasi yang berdampak kepada kualitas layanan publik.Penelitian ini mencoba menyajikan tentang analisa penilaian kinerja pegawai dengan menekankan kepada kualitas-kualitas yang ditentukan (kompetensi) dalam upaya meningkatkan kinerja organisasilayanan publik di Indonesia sehingga dapat dilihat pengukuran kinerja dapat dijadikan acuan sebagai ukuran kinerja suatu organisasi.Riset yang dilakukan memakai studi tinjauan pustaka danmemakai pendekatan kualitatif dalam menganalisa data-data yang disajikan dalam penelitian.Studi menemukan bahwa pegawaipada umumnya di evaluasi oleh atasan mereka langsung.Berkenaan dengan frekuensi kenaikan jabatan dalam organisasi, setiap pemimpin menjelaskan bahwa organisasi mempunyai pola yang jelas dalam menetapkan kenaikan pangkat dan jabatan tersebut, dimana hal ini merupakan kewenangan manajemen.Akan tetapi terkadang pemimpin organisasi membiarkan faktor bias seperti masalah gender, masalah penampilan, suku atau ras tertentu atau perasaan benci terhadap seseorang mempengaruhi penilaian mereka. Kecuali penilaian didasarkan pada kinerja pekerjaan yang sebenarnya, evaluasi akan terus dilakukan tanpa tujuan yang sering dibutuhkan dalam sistem penilaian kinerja yang adil.
\end{abstract}

Kata Kunci: Kinerja Pegawai; Penilaian Kinerja; Organisasi; Manajemen; Layanan Publik.

\section{INTRODUCTION}

The public service sector in most countries, big and small, is experiencing significant reform to improve services while still sharply reducing costs in the face of severe budgetary constraints. "A critical component of those public sector improvements is continuingworktotransformpublicadministrationand reimagine governance through common expressions" (Wholey, 2007; Van Dooreen et al., 2015). The public management reform process is crucial to address the dual task of expanding programs when operating on a shoestring budget. The Performance Appraisal System is one of the most widely used instruments for reform practices today. "Improving government efficiency - increasing the productivity, consistency, accessibility, and efficacy of public bodies and initiatives - is critical for all, both as beneficiaries of public services and as taxpayers." (Christensen \& Laegreid, 2007) As Wholey also argued, a host of political, bureaucratic, and technological limitations morphed into efficiency constraints. Additionally, everywhere performance appraisal is used, it is seen as a particularly contentious management technique.

According to others, companies have never adequately assessed their workers' efficiency, which affects their job motivation (Mayer \& Davis, 1999; Christ et al., 2012). Executives or leaders measure 
achievement based on their understanding of intrinsic qualities, such as management obedience, but without precise results to which traits can be attributed (Kaiser et al., 2008).

The primary objective of performance assessment is to evaluate an individual's success over a specified period to determine areas of success and vulnerability and to establish benchmarks to be met to achieve the organization's strategic objectives (Abdullah, 2014). Recognizing that company outcomes are primarily determined by employee success, many executives are looking for novel ways to boost performance (Abbas \& Yaqoob, 2009) dramatically. Employment importance or metric is determined by comparing the frequency of occurrence of different variables in a job, such as requisite experience and abilities, degree of obligation, decision-making authority, and effect on results, to the frequency of occurrence of the same factors in other occupations (Porter et al., 1974).

To ensure public service organizations' success, the degree to which productivity growth and management are prioritized is critical; therefore, the core of labor productivity and welfare is knowledge and inspiration. Top management's function is to organize managers' attempts to maximize efficiency (Kiwang et al., 2015).

The performance evaluation scheme is primarily defined by the fact that the appraisal findings are not disclosed to workers. According to Kellough \& Selden (2003), the apparent secrecy of these performance assessment reports is often put in the custody of superiors and managers, providing an opportunity for supervisors and managers to use impunity to discipline "recalcitrant" workers. The primary goal of performance assessment is to establish a logical foundation for determining and managing internal relativity between workers and designing compensation systems (Baker et al., 1988).

Evaluation of results acts as a management information system for organizations that provide workers with input on their performance. It is widely recognized as a legitimate way of efficiently assessing, tracking, and using employees at all enterprise levels (Purnama, 2016). Thus, management is responsible for establishing a structured process for monitoring and evaluating employee contributions to corporate objectives.

Bernardin \& Wiatrowski (2013) define performance assessment as a fully orchestrated framework that entails daily scheduled meetings between managers and total employee performance against predetermined targets and managers training and advising employees on areas requiring corrective action to enhance overall performance. To the good of workers and the company as a whole.

Although Churchill et al. (1993) made similar findings suggesting that performance assessment could serve as the foundation for employee selfesteem and sound organizational systems for staff coaching and development, they have proposed to rely on performance data for promotions and pay rises. Management supports workers in assessing their talents and weaknesses rather than favoritism, subjectivity, observation or success assessment. This will encourage employees to perform at an increased pace.

Budiharjo (2015) stresses the importance of a superior evaluating a person's success regularly. An appraiser is usually someone with considerable knowledge and understanding of the job. He should be familiar with the job and the defined performance criteria, someone who knows and whose personal attributes or characteristics should be evaluated, and put in a superior role to experience the evaluation for a suitable period. As a result, managers are often placed in the most favorite part to evaluate the assessment (Anwaruddin, 2006). The categories of products appraisals are as follows;

a. Superiors' evaluations (supervisors or line managers). It is common practice in the world for a boss, who is typically an employee's immediate superior, to be assigned to review his subordinates' results. This is because, as an employee's boss, he or she has the best opportunity to observe, guide, and reflect on employee results during the assessment time being checked.

b. Peer Evaluations. In this scenario, the employee serves as the appraiser, with each employee evaluating his or her fellow employees. Peer assessment is founded on the premise that workers, particularly those who operate in tight clusters, have firsthand knowledge of one another's success levels and are better equipped to score one another on various personality traits.

c. Evaluation of Subordinates. Appraising subordinates demands that their associates evaluate the superior's success. This approach is not widely known in the industry, owing to the industry's "chain of command" framework. The benefit of this approach is that the manager can see himself from the "eyes" of another human, which enables him to make appropriate changes.

d. Self-Evaluation. The need for self-development, coaching, and counseling necessitates assessing each employee's success and skills. The most common approach is for superiors and subordinates to collaborate on a list of assignments to be 
completed (using management techniques with objectives). Associates are given the ability to evaluate their results against predetermined goals in this scenario. In doing so, the employee will know that he or she has not accomplished enough to warrant an incentive to succeed before the next self-assessment date.

e. End-Users. Often, the consumers of the facilities have the most accurate measurement of employee results - for instance, an airline flight attendant's appearance, politeness, and performance.

Performance analysis is classified into two types: confidential (closed) and accessible (open). A closed structure maintains the confidentiality of all levels, procedures, and final reports and does not report them to subordinates or staff. He has no input on the outcome, is unaware of his strengths and limitations, and takes no action to improve his success. A transparent approach to assessment is a method of evaluation in which all steps and procedures of the assessment process and the outcomes are published and shared with the staff or subordinates concerned. No part of the assessment process is imprudent because, in this context, the subordinate's strengths and shortcomings are addressed, and solutions are found to enhance those areas.

Another alternative is the conventional/ common approach, which is associated with a superior taking on a "do-it-yourself" psychologist. Nalbandian (1981) defines this strategy as one that puts the boss in an untenable situation to evaluate subordinates' values and behave accordingly. Assessment activities are often viewed as annual ritual assignments that must be performed promptly. Often, completing the evaluation form is seen as the conclusion of the procedure, when in reality, it is the beginning (Cederblom, 1992).

Performance assessment functions can be defined as either evaluative or evolutionary, depending on the organization's objectives (Brown et al., 2010). According to Whetten etal. (2007), the aim is to assess employee effectiveness, find areas for improvement, evaluate their compensation, and determine their suitability for training. Both agree that the appraisal will provide feedback for management decisionmaking, act as a basis for counseling, guidance, and counseling, and is often emphasized by physicians and others as the primary role in performance evaluation. Supervisors are not immune from assessment, and companies do not necessarily adhere to standardized or specific performance appraisal goals or sets.

The best approach is to establish priorities for the group as a whole and each member individually.
This is frequently the case during successful teambuilding sessions and quality circles. The groups agree on shared objectives, and active measures are then defined to indicate who will do what and when. When tasks are interdependent, establishing group objectives promotes greater collaboration and collaboration within the group. As a consequence, the efficiency of the company increases. Planning is the first step toward increased efficiency. When work is interdependent, the optimum approach is to set targets for the organization and each member. Setting goals for the group promotes a greater degree of collaboration and coordination within the group.

\section{METHOD}

In Indonesia, qualitative research on performance evaluation and its effect on enhancing the performance of public service organizations is used. A qualitative approach to science is a set of investigations and interpretations that focuses on social phenomena and human issues. The researcher creates a vivid view in this analysis by delving into words, reporting in detail, and analyzing the state of nature (Creswell, 2015). Additionally, researchers must have a critical mindset and diverse perspectives to ask pertinent questions, analyze, and build the object under examination to make it more understandable. This research is mainly concerned with context and meaning. The essence of research is that it fosters friendships between people who have an interest in their environment.

This thesis employs a literature review methodology to assess theories that can be generalized to the test object. The assessment of the concepts and approaches used in this section is based on the available literature, significantly articles published in various scientific journals. Literature research aims to generate theories or ideas related to experimental studies (Sujarweni, 2014). A literature review is a critical activity in science, especially scientific analysis, whose primary goal is to develop theoretical and practical aspects so that the writers will efficiently resolve the issue that would be analyzed using this research method.

\section{RESULTS AND DISCUSSION}

Quality control includes preparation to ensure that goals are met consistently and successfully. Performance control may focus on the organizations, divisions, product or service production processes, or personnel performance. This topic would include an outline of all practices associated with employee success management. 
"Planning" entails establishing successful objectives and priorities for the organization and directing people's efforts toward achieving those goals. Additionally, it includes indicators that can be used to determine what objectives and expectations have been reached. Employee involvement in the planning process enables employees to understand corporate priorities, what needs to be accomplished, why it needs to be completed, and how easily it can be achieved (Yadrifil \& Lithrone, 2008).

Employees are not necessarily willing to do what they want. On the one side, they present themselves as capable practitioners. They point the finger at someone when their tasks do not work out. Best of all, workers become defensive as you want to prepare them to do well and meet objectives. Quality control is the solution in this case (Ruky, 2002).

When an individual struggles at work, it is critical to wonder, "what about the work system contributed to the person's failure?" Sometimes, as workers understand what they are meant to do, the solutions will present themselves - whether in the form of time, tools, preparation, disposition, or ability. Tools, time, and planning are the easiest to overcome and affect employee satisfaction. Employees must be supplied with the required resources, time, and training to carry out their duties efficiently (Ridlo, 2012).

These are the critical questions that you and your staff want to be addressed to diagnose the performance problems that necessitate performance management. This employee performance assessment checklist will assist you in diagnosing performance problems.

Understanding these performance improvement challenges allows a supervisor to assist an individual in achieving success. By following these actions and responding to these questions in the performance assessment model, you will assist the employee in succeeding and wishing you the best of luck with your success management. Performance assessment is the most effective method for promoting and training employee productivity (Baharun, 2016).

The majority of administrators have discovered that supervisors' directives cannot do practical work. Person encouragement is essential for increased employee productivity. Whereas the single most critical problem in handling people in the workplace is inspiration, teamwork, and connectivity, they are likely to mention these. Motivation energizes the human spirit. It is the force that motivates people to meet their basic needs. Any aspect of human action is geared toward a specific objective. The critical element is the path toward which the inspiration is directed - it is toward working hard and doing highquality work or sleeping as much as possible at work without being caught. Motivation has been a primary focus of administrators and social scientists for the better part of the past three decades.

Productivity is critical for a country's industrialization and economic growth to accelerate. This is typically accomplished by a workforce achieving milestones that inspire other people to do the same. Still, regardless of whether it is a government, an organization, or a (religious society), they will have a common goal: accomplishment.

In general, organizational efficiency refers to management's willingness to inspire employees to act confidently and discernibly against company objectives (Marliani, 2016). Motivation and efficiency mean that administrative activity is necessary to boost morale to accomplish collective objectives, and therefore are essential for confidence and teamwork to be visible on both sides. Motivation is at the heart of productivity. This is the labor productivity's ability to demonstrate the efficacy of which it has been combined with other output variables.

According to Yudhaningsih (2011), one effective way to boost competitiveness is to promote human performance at work. For businesses, the outcomes of a motivation survey can result in a rise in efficiency, a reduction in attrition, a decrease in absenteeism, and a more efficient work environment. Understanding the factors that contribute to moral elevation can result in increased satisfaction and self-realization for the person.

Regardless of their origins, today's organizations must have their own set of goals and priorities to function effectively. To accomplish the organization's priorities and strategies, workers must be empowered to perform at their best. There must be a good motivation for workers to behave following management expectations. Management must include an incentive package for its employees to increase their production potential.

The term "Organizational Reward System" refers to a deliberate and coordinated mechanism for increasing employee effectiveness or staff efficiency by providing several rewards. According to Ainanur \& Tirtayasa (2018), "this situation is one under which the association should motivate its members to continue involvement, thus ensuring the organization's longevity."

However, in the true sense of the word, the corporate incentive system plays a particular and essential role. Murti (2012) claims that "introducing pay compensation systems into organizations with 
underperforming supervisors can and often results in greater improvements in productivity per headon-person than introducing the system into an organization with a strongly qualified supervisor."

Administration bonuses, such as higher wages, will motivate employees to learn and perform complex assignments on the job, showing "good performance" daily and restoring equilibrium. The implications for management are that it is critical to decide whether the current scheme's intended results can be accomplished as quickly as possible to maximize compliance. And an employee's desire to perceive a positive connection between his salary and his company has a direct impact on his willingness to optimize his productivity while employed under a pay compensation scheme.

Chenhall \& Langfield-Smith (2003) assert that "organizational compensation programs essentially increase employee efficiency by the opportunities for accomplishment, responsibility, promotion, appreciation, and confidence development." GouidWilliams (1987) adds that incentives can increase workers' motivation for specific activities or a desire to be sure to bolster this argument.

Compensation is a monetary reward for the services rendered by employees (Irbayuni, 2012). Martono et al. (2018) define prizes as cash compensation (wages, salaries, and honoraria, as well as present and future incentives) used to confer awards. Similarly, Increasing advantages are described in Mehomood et al. (2013) as direct monetary payments and indirect monetary advantages. The previous word seems too narrow. They exclusively equate donations with cash gains. Even if it's just a money profit. The payments are non-additional, though they pay for about one-third (or more) of the organization's expenditures.

Rewards can also be defined as all direct financial incentives plus indirect payments (benefits) plus individual incentives within an organization, plus non-compensatory remuneration - all aspects of a good work experience that lead to self-esteem and acceptance and appreciation by others of a person. In other words, wages and incentives in return for jobs.

Ensuring, retaining and motivating workers is the goal of efficient pay and benefits schemes. It doesn't occur. There must be some conditions to this effect, and four (4) of them must be defined:

1. Reward systems that are appropriate or necessary to satisfy specific requirements.

2. Employment equity concerning the external labor market

3. Corporate equity is equitable compensation for employee commitments to organizational objectives.
4. Treatment of each hospital employee following their individual needs.

They assume it is an instinct to action that can be activated externally or produced internally, based on the individual's participation in such activities due to the anticipated final reward. The truth remains that no employee is likely to devote significant time or effort to execute acts he perceives as futile, especially if he believes he has failed or anticipates an insufficient incentive.

Additionally, the corporate incentive structure can be viewed from the lens of the external motivation philosophy, which argues that most of an individual's power is added to variables governed by management, such as pay, working circumstances, organizational policies, recognition, advancement, and accountability. At all times, it is essential for workers' motivation.

The external incentive hypothesis is based on whether employees react positively or adversely to anything management does. The external incentive is essential for management because it means that employees are working toward fulfilling corporate goals and strategies. Numerous reasons contribute to inspiring advertisers to increase their efficiency. That includes pay and pensions, compensation schemes, job ethics and societal principles, morality, physical and psychological working environments, management leadership quality and appearance, workforce experience and skills, and management reward programs. Any new behavior that is to persist must be constantly praised. The accuracy and efficacy of the incentive are determined by the amount of reinforcement received.

According to Hanggraeni (2012), three factors must exist for workers to be effectively motivated to work at the required stage:

1. The benefits of employment must be understood and explained plainly.

2. Individuals should be compensated with particular performance enhancements.

3. Reward systems should be as closely related to target success as possible.

To do this, we need a system of communication that gives positive reinforcement priority. To track gang output and provide input, accurate information systems are required. They must recognize their job first to inspire and encourage people to be successful.

Surprisingly, research on money as a motivator for increased efficiency yields mixed results on its efficacy. Income satisfies a variety of financial and psychological needs. The difficulty in comprehending 
money's function as a motivator of growth is the breadth of its application and the problems inherent in isolating its power from other motivators. Who is so concerned about the scale and value of the wage bundle in a world where fundamental demands are not adequately met?

Employees' behavior in the workplace is deemed to be either constructive or disrespectful by their immediate boss. The positive effect is critical when it comes to employee involvement. As a result, the first step toward fostering commitment is to increase management expectations. Much has been published recently on the importance of improving our workforce's readiness and training. Although it is essential, it should receive at least equal consideration. To improve management practices if the company wishes to increase employee satisfaction and, therefore, sales.

The advantages of hiring the highest-skilled employees and using cutting-edge technologies can negate managers' bad people management strategies.

According to Shahid \& Azhar (2013), a continued dedication to and promotion of consistency in customer care are two critical components of success in today's rivalry and accelerating transition, as well as prosperous and enlightened staff management. The latter bore 'commitment, which results in the achievement of desired customer service levels.

Leaders or managers also refuse to recognize that some of the most successful strategies for developing and retaining engaged and dedicated workers are inexpensive or free.

Consider the strengths of "my toddler":

1. Attractive Job: No one enjoys repeating the same tedious task day after day. And, while every career would often involve boring and routine jobs, everyone should be involved in at least some of their jobs.

2. Information: Knowledge is a strength, and workers deserve to be provided with the knowledge they need to do their roles more successfully and efficiently. And, more than ever, managers tend to understand their work and the organization's best practices. Enable workers to obtain information, ask questions, and exchange information through open communication networks within the company.

3. Engagement: Today's executives face a plethora of opportunities and challenges. While the speed of the industry continues to accelerate, the amount of time available for decision-making begins to shrink. Involving workers in decisionmaking is both compassionate and realistic, particularly where the decision directly affects them. Generally, the closet provides the most insight into what to do. By including others, you maximize their dedication and their ability to implement new strategies or improvements.

4. Independence: Certain workers desire constant monitoring of their every move. The majority of workers value the freedom to carry out their duties in how they see fit. Allowing people to act in how you want increases their likelihood of doing so and brings more effort, ideas, and enthusiasm to their work.

5. Increased Visibility: Everybody appreciates receiving compliments on time. The possibilities for sharing employee achievement with others are almost endless. Providing unique ways for workers to learn and improve as a token of appreciation and respect is very rewarding for most people.

\section{CONCLUSION}

The scoring system is mainly characterized by the non-disclosure of the results of the rate assessment. The confidentiality of the outcome of this success helps position leaders and administrators as a possible weapon to suppress 'subordinates who do not comply with immunity.' Coherence managers also have prejudices that affect their rank, for example, the sex of a person who perceives race, personal likeness or hate. Unless assessments are focused on actual work results, the objectivity often demanded in objective performance measurement processes may be ignored by evaluations.

In general, various causes or issues may impede the efficiency and occupational success measured in the business. Incorrect nature of evaluation formula, disappointing performing assessment outcomes resulting in loss of confidence in assessment systems; performance care as an annual routine, all of it indignation with no substances. These include lack of objectivity, lack of expectations and targets. In addition to these other considerations, feelings and politics depend on personal characteristics instead of job efficiency.

\section{REFERENCES}

Abbas, Q. \& Yaqoob, S. (2009). Effect of Leadership Development on Employee Performance in Pakistan. Pakistan Economic and Social Review, 269-292.

Abdullah, M.R. (2014). Manajemen dan Evaluasi Kinerja Pegawai. Banjarmasin: UIN Antasari 
Ainanur, A. \& Tirtayasa, S. (2018). Pengaruh Budaya Organisasi, Kompetensi dan Motivasi terhadap Kinerja Pegawai. Maneggio: Jurnal Ilmiah Magister Manajemen, 1, (1), 1-14.

Baker, G.P., Jensen, M.C. \& Murphy, K.J. (1988). Compensation and incentives: Practice vs. theory. The journal of Finance, 43, (3), 593616.

Bernardin, H.J. \& Wiatrowski, M. (2013). Performance Appraisal. Psychology and Policing, 257.

Brown, M., Hyatt, D. \& Benson, J. (2010). Consequences of The Performance Appraisal Experience. Personnel Review.

Budihardjo, I. M. (2015). Panduan Praktis Penilaian Kinerja Pegawai. Raih Asa Sukses.

Chenhall, R.H. \& Langfield-Smith, K. (2003). Performance Measurement and Reward Systems, Trust, and Strategic Change. Journal of Management Accounting Research, 15, (1), 117-143.

Christ, M.H., Emett, S.A., Summers, S.L., \& Wood, D. A. (2012). The Effects of Preventive and Detective Controls on Employee Performance and Motivation. Contemporary Accounting Research, 29, (2), 432-452.

Christensen, T. \& Lægreid, P. (2007). The Wholeof-Government Approach to Public Sector Reform. Public Administration Review, 67, (6), 1059-1066.

Churchill, G.A., Ford, N. M., Walker, O. C., Johnston, M.W. \& Tanner, J.F. (1993). SalesForce Management. Homewood, IL: Irwin.

Creswell, J.W. (2015). Penelitian Kualitatif dan Desain Riset, terj. Ahmad Lintang Lazuardi, $d k k$. Yogyakarta: Pustaka Pelajar.

Gould-Williams, J. (2003). The Importance of HR Practices and Workplace Trust in Achieving Superior Performance: A Study of PublicSector Organizations. International Journal of Human Resource Management, 14, (1), 28-54.

Hanggraeni, D. (2012). Manajemen Sumber Daya Manusia. Depok: Universitas Indonesia Publishing.

Kaiser, R.B., Hogan, R. \& Craig, S.B. (2008). Leadership and The Fate of Organizations. American Psychologist, 63, (2), 96.
Kellough, J.E., \& Selden, S.C. (2003). The Reinvention of Public Personnel Administration: An Analysis of The Diffusion of Personnel Management Reforms in The States. Public Administration Review, 63, (2), 165-176.

Kiwang, A.S., Pandie, D.B., \& Gana, F. (2015). Analisis Kebijakan dan Efektivitas Organisasi. JKAP (Jurnal Kebijakan dan Administrasi Publik), 19, (1), 71-82.

Marliani, J. (2016). Kompetensi Merupakan Faktor Penentu Dalam Meningkatkan Kinerja Pegawai Di Bidang Pengadaan Dan Pengembangan Badan Kepegawaian Daerah Kabupaten Subang (Doctoral dissertation, Universitas Pasundan).

Martono, S., Khoiruddin, M. \& Wulansari, N.A. (2018). Remuneration Reward Management System as A Driven Factor of Employee Performance. International Journal of Business \& Society, 19.

Mayer, R.C. \& Davis, J.H. (1999). The Effect Of The Performance Appraisal System On Trust for Management: A Field Quasi-Experiment. Journal of Applied Psychology, 84, (1), 123.

Mehmood, S., Ramzan, M. \& Akbar, M. T. (2013). Managing Performance Through Reward System. Journal Of Humanities And Social Science, 15, (2), 64-67.

Murty, W.A. (2012). Pengaruh Kompensasi, Motivasi dan Komitmen Organisasional Terhadap Kinerja Pegawai Bagian Akuntansi (Studi Kasus pada Organisasi Manufaktur di Surabaya) (Doctoral dissertation, STIE Perbanas Surabaya).

Nalbandian, J. (1981). Performance Appraisal: If Only People were not Involved. Public Administration Review, 41, (3), 392-396.

Porter, L.W., Steers, R.M., Mowday, R.T. \& Boulian, P.V. (1974). Organizational Commitment, Job Satisfaction, and Turnover Among Psychiatric Technicians. Journal of Applied Psychology, 59, (5), 603.

Purnama, C. (2016). Sistem Informasi Manajemen. Mojokerto: Penerbit Insan Global.

Ridlo, I.A. (2012). Turnover Pegawai "Kajian Literatur". Surabaya: Public Health Movement. 
Ruky, A.S. (2002). Sistem Manajemen Kinerja. Jakarta: Gramedia Pustaka Utama.

Semiawan, C.R. (2010). Metode Penelitian Kualitatif. Grasindo.

Shahid, A. \& Azhar, S. M. (2013). Gaining Employee Commitment: Linking to Organizational Effectiveness. Journal of Management Research, 5, (1), 250.

Sujarweni, V.W. (2014). Metodologi Penelitian: Lengkap, Praktis, dan Mudah Dipahami. Yogyakarta: Pustaka Baru Press.

Van Dooren, W., Bouckaert, G. \& Halligan, J. (2015). Performance Management in The Public Sector. Routledge.
Whetten, D.A., Cameron, K.S. \& Woods, M. (2007). Developing Management Skills. NJ: Prentice-Hall.

Wholey, J.S. (2007). Monitoring Performance in The Public Sector: Future Directions from International Experience. Transaction Publishers.

Yadrifil, Y. \& Lithrone, L. (2008). Perencanaan Strategi Dalam Upaya Menyelaraskan Tujuan Organisasi dan Tujuan Pegawai dengan Pendekatan Total Performance Scorecard (Studi Kasus Departemen Internal Audit Organisasi Minyak dan Gas Bumi). Jurnal Teknik Industri, 10, (2), 138-150. 